\title{
In memory of R. D. Laing
}

\author{
Anthony S. DAVID, Honorary Lecturer, Institute of Psychiatry, De Crespigny Park, \\ Denmark Hill, London SE5 8AF
}

When the maverick psychiatrist $R$. D. Laing died on 23 August 1989 at the age of 61 , it reached the front pages of several newspapers. There he was described as the "pop" psychiatrist and "counter-culture guru" and much irony was wrung from the circumstances of his untimely demise, not in his study or consulting room, but on a tennis court in St Tropez. The obituaries which appeared subsequently were understated by comparison, tending towards a solemn appraisal of this remarkable figure and his controversial writings. Due emphasis was given to his empathy, his championing of the repressed, his at times hyperbolic rhetoric.

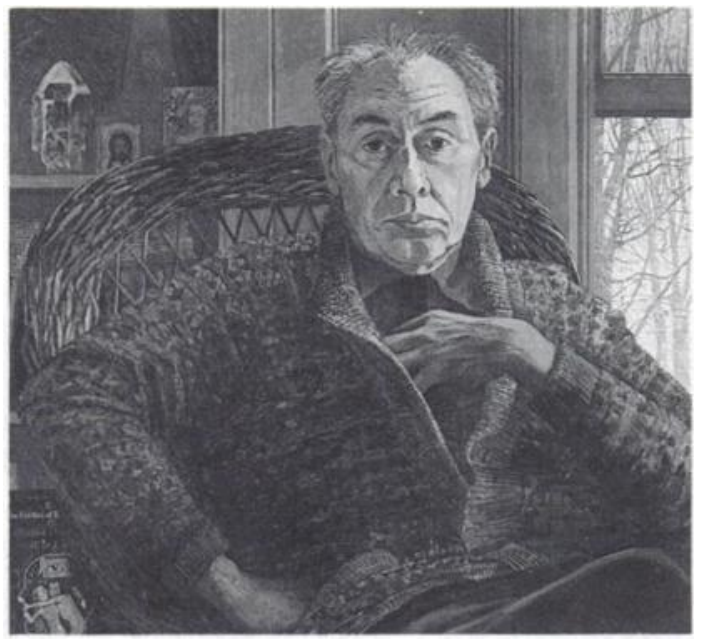

R. D. Laing (Victoria Crowe). Reproduced by permission of Scottish National Portrait Gallery.

The facts of his life are fairly well known: from his dour West of Scotland upbringing and medical training in Glasgow, his first book The Divided Self, written before he was 30 , his subsequent studies on families of schizophrenic patients, leading up to his most celebrated publications in the late 1960 s on madness as an existential journey and society as an instrument of psychic repression. Later he did the American college lecture circuit, went to the east to study meditation, and was generally fêted as a celebrity. He continued to write but less as a scholar and thinker, more as a commentator on a wide range of topics, vehemently critical of the medicalisation of childbirth and even of psychoanalysis. He described conversations with his children and tried his hand at poetry, he even recorded an LP of some songs, and answered letters as an 'agony aunt' for a women's magazine. The Divided Self has sold around 400,000 copies and The Politics of Experience and The Bird of Paradise over $\frac{1}{2}$ a million. Much of the time he continued as a therapist and supervisor. He never described his own approach to treatment. His last book was the first volume of an autobiography which, though interesting and full of charm, was disappointingly superficial. One hopes there is more to come, albeit posthumously.

Following Laing's death Anthony Clare reflected upon his influence in the Guardian newspaper. Clare paid him warm tribute, saying his decision to become a psychiatrist followed reading The Divided Self. How many of us would say the same? Hundreds, maybe thousands? Few psychiatrists would claim to be Laingian, most while admitting the profound impression Laing made on them would look back on him as they would a schizophrenic son with a mixture of pity and embarassment. What was it about him that was so inspiring? His writing could be dense and convoluted as well as lucid. He was a poor public speaker given to indulging in antics. The answer, I think, lies in two things. Most important was the impression he created, perhaps justifiably, that he alone could form an alliance with the most withdrawn and uncommunicative patient. It was courage plus more than a hint of youthful arrogance that led him to conclude that his inability to elicit the signs and symptoms of psychosis was not a deficiency on his part but that they (authors of psychiatric textbooks) were wrong. Where they saw an organism malfunctioning, he saw a person struggling for existence. It is with this ideal in mind that many people post-Laing entered psychiatry.

The other facet was the breadth of his scholarship, covering philosophy, anthropology and literature. He was a true intellectual in the European tradition. His sources were Sartre, Heidegger, Kierkegaard, Kafka, Dostoyevsky, Freud. To be well versed in the humanities as well as medically trained is another ideal of the aspiring psychiatrist. I remember reading essays published in the Glasgow University medical magazine while he was still a student on such 
portentous subjects as 'Philosophy and Medicine' and 'Health and Society' feeling distinctly ill-read.

Far more contentious is Laing's standing as a psychiatric researcher. When criticising the early twin studies of Slater and Kallmann, the major flaw in this work, namely diagnostic bias, is mercilessly exposed. Laing knew what constituted sound research methodology but chose to approach the study of psychosis in a completely different way which can rightly be termed unscientific. He could be thorough and painstaking as evidenced by the data gathered for Sanity, Madness and the Family (1964) but he refused to be objective. Objectivity he took to mean, somewhat concretely, viewing a person as an object, which he believed was the cardinal sin of psychiatry and the beginning of the alienation process. Nevertheless while defiantly subjective, the descriptions of the depersonalisation of early schizophrenic breakdown to be found in The Divided Self show he possessed a keen phenomenologist's ear and immense clinical skill. Although he set out to blur the distinction between the meaningful and the causal, he had a thorough knowledge of Jaspers and might even have studied under him in Heidelberg had he not been discouraged by seniors who felt the professor had become "too philosophical".

It is interesting to speculate upon the course R. D. Laing's reputation would have taken had he lived another decade or two. Would he have become a grand old man of letters complete with a conciliatory honorary fellowship of the College? I suspect not. Psychiatry in the 21 st century will still be too insecure about its status as a science to admit to the notions of transcendence that Laing espoused. Furthermore, too many clinicians and patients' relatives will not have forgotten the atmosphere he helped to create whereby families were blamed for inducing schizophrenia in their children. Nevertheless, I believe that he should be credited with influencing mainstream psychiatry in constructive ways. These include fostering a sympathetic attitude to persons suffering from schizophrenia and preparing the ground for family studies which would confirm the importance of family relationships in determining psychological well-being. On the other hand he fostered an unsympathetic attitude to persons practising psychological medicine, especially where this included the use of physical treatments. His views on the management of psychiatric patients which was at best regimented and at worst inhumane were widely shared by many psychiatrists. However, the work of social psychiatrists had already started to improve conditions in asylums by the time Laing's opinions were disseminated. He was never anti-psychiatry per se but rather pro a non-interventionist attitude to persons suffering mental distress. His founding of the Philadelphia Association and the Kingsley Hall therapeutic community is best viewed in the spirit of the retreat or asylum in the pure sense of the term. In this Laing is oddly reactionary when set against the revolutionary spirit of community care circa 1960-1970.

Would he have wished to become a member of the establishment even if invited to do so? My guess is that he would not. While there was definite tempering of his views over the years his fundamental antipathy to the perspective from which psychiatrists viewed their subject and use of the so-called medical model as exemplified by the DSM-III, remained intransigent. I met Laing just twice. My abiding memory of him was a sudden animation when talking about the future of our discipline. On one occasion, he picked up a copy of the DSM-III and read out from its glossary the example provided of "poverty of content of speech". The hesitant account given by the patient in answer to the question as to why people believed in God, was from Laing's reading, like some Old Testament prophet, transformed into a sermon. "If I had been able to answer as well as that I would be in a state of grace, never mind being schizophrenic", he boomed. His antagonism to psychiatry often became personalised. This was not limited to figures from the past as in his famous hatchet job performed on Kraepelin in The Divided Self, but included highly respected contemporaries such as John Wing and Eliot Slater. Professor Wing countered with equal force and derision in reviews and books. An eventual rapprochement between these figures and the ideologies they represent would have been inconceivable. However they had in common a deep commitment to improving the fate of schizophrenic persons. Both illustrate their respective self-images as physicians, with the same quotation from Camus' The Plague: “. ... who, while unable to be saints, but refusing to bow down to pestilences, strive their utmost to be healers".

Laing was the rebel who like a stroppy adolescent paved the way for psychiatry to mature. He was Rousseau to Wing's Voltaire, Delacroix to his Ingre. Like him or loathe him, he was necessary.

As with Freud and Jung, Laing's greatest impact is likely to be found outside psychiatry, in the arts and social sciences. Comparison with Jung is relevant in that both began their careers in a mental hospital setting with an interest in schizophrenia (Laing regretted his move to the Tavistock Clinic despite respect for his supervisors Marion Milner and Charles Rycroft because of its out-patient emphasis) and later explored social anthropology, mysticism and religious faith. Laing's fame will remain less than Jung's since his creative output was inconsistent and, perhaps through an enduring distrust of institutions, he did not cultivate an official 'school' of theory and practice.

Perhaps the words which best convey the legacy of R. D. Laing are to be found in Auden's poem 'In Memory of Sigmund Freud': 
"if he was wrong and, at times, absurd, to us he is no more a person now but a climate of opinion under whom we conduct our different lives."

Summing up his attitude to psychiatry he wrote: "No facts are in dispute. I believe that to give serious consideration to the issues that arise from seeing the same (facts) differently itself contributes to lessening some of the fear, pain, madness and folly in the world" (Laing, 1985).

\section{Selected references}

AUDEN, W. H. (1974) In memory of Sigmund Freud. International Review of Psycho-Analysis, $1,3$.
Clare, A. (1989) A divided view of madness. Guardian, 25 August, p. 21.

DAVID, A. S. (1986) Books reconsidered: Sanity, Madness and the Family. British Journal of Psychiatry, 149, 379-381.

Evans, R. (1976) R. D. Laing: the Man and his Ideas. New York: E. P. Dutton \& Co.

LaING, R. D. (1949) Philosophy and medicine. Surgo, June, 134-135.

- (1960) The Divided Self. London: Tavistock.

- \& Esterson, A. (1964) Sanity, Madness and the Family. London: Tavistock.

- (1967) The Politics of Experience and the Bird of Paradise. Harmondsworth: Penguin Books.

- (1985) Wisdom, Madness and Folly: the Making of a Psychiatrist. London: MacMillan.

WING, J. K. (1978) Reasoning about Madness. Oxford: Oxford University Press.

\section{Miscellany}

\section{Charities}

The Manic Depression Fellowship Ltd aims to help sufferers of manic depression and their relatives; to educate the public about this illness and to fund research for a cure. Both sufferers and relatives are eligible for membership and the Fellowship offers a quarterly newsletter, local self-help groups and open meetings, pen-friendship scheme and information sheets, and international news. Further information: David Young, Public Relations Officer, The Manic Depression Fellowship Ltd, 51 Sheen Road, Richmond upon Thames, Surrey TW9 IYQ.

Good Practices in Mental Health (GPMH) is a national charity set up to disseminate information about local mental health services which are found to work well. By providing an exchange of information about effective services in hospitals and the community, GPMH encourages others to build on what is already proving successful in order to promote and assist the development of good mental health services. Details of its activities are included in their Annual Report 1988-89. Further information: Judy Renshaw, Director, Good Practices in Mental Health, 380-384 Harrow Road, London W9 2HU.

\section{Bulletin of the Menninger Clinic}

In 1990 the Bulletin of the Menninger Clinic (a journal for mental health professionals) will change its publication frequency from six times a year to quarterly. However, the total number of the journal's editorial pages per year will not be reduced. The visual appearance of the journal will also change. Further information: Philip R. Beard, Managing Editor, Bulletin of the Menninger Clinic, The Menninger Foundation, Box 829, Topeka, KS 66601 0829, USA.

\section{Request for back copies of the Journal}

The Schizophrenia Research Foundation (India) is a voluntary, charitable, non-governmental organisation working for people with chronic mental illness. Founded in 1984 by a group of philanthropists and mental health professionals, the Foundation works towards objectives of research, rehabilitation and public education in the field of schizophrenia on a very small budget. Their library is extremely small and they would welcome runs of back issues of the Journal. They should be sent to: Dr Vijay Nagaswami, Assistant Director (Research), Schizophrenia Research Foundation (India), No. C-46, 13th Street, East Anna Nagar, Madras, India.

\section{New publication}

Community Psychiatric Service in Mental Handicap: Six Years of Experience. By N. Bouras and K. Drummond, 1989. $£ 5.00$ (UK); $\$ 7.50$ (USA) including postage and packing. Available from NUPRD, Lewisham Hospital, Lewisham, London SE13.

This is the second report in a series which describes the activity of a new psychiatry of mental handicap community service. The first report documented the assessment and clinical management of new referrals during the first five years. This report updates the existing data. It focuses on continued involvement with clients, as the population served has life-long disabilities and recurrent needs. The report presents information about demographic and clinical characteristics of clients, including psychiatric disorders and degree of handicap, and raises many issues related to current service provision for adults with a mental handicap. 